\section{THE RELATIONSHIP BETWEEN PUBLIC AND PRIVATE HEALTH INVESTMENT AND ECONOMIC DEVELOPMENT BASED ON THE OVERLAPPING GENERATIONS (OLG) MODEL}

\author{
RELAÇÃO ENTRE INVESTIMENTO PÚBLICO EPRIVADO EM SAÚDE EDESENVOLVIMENTO ECONÔMICO COM \\ BASE NO MODELODE GERAÇÕES SOBREPOSTAS (OLG)
}

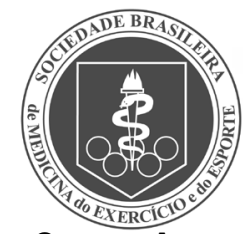

Original Article

ARTIGO ORIGINAL Artículo Original

\author{
INVESTIGACIÓN SOBRE LA RELACIÓN ENTRE LA INVERSIÓN EN SALUD PÚBLICA Y PRIVADA YEL \\ DESARROLLO ECONÓMICO A PARTIR DEL MODELO DE GENERACIÓN SUPERPUESTA
}

\begin{abstract}
Shuihui Jiang' (DD
(Public health Education)

1. School of Statistics and Mathematics, Henan Finance University, Zhengzhou, Henan, 450046, China.
\end{abstract}

\section{Correspondence:}

Zhengzhou, Henan, 450046, China. cydwmc52@sina.com

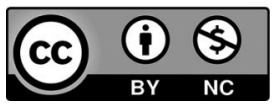

\begin{abstract}
As an important part of human capital, healthy human capital plays a great role in promoting economic development. Based on the overlapping generations (OLG) model, this study establishes a correlation analysis model between healthy human capital and economic growth. This model takes utility maximization as the theoretical carrier to study how individuals promote economic growth while pursuing the maximization of their own health capital accumulation. The model can analyze the promotion mechanism of healthy human capital on economic growth, so as to provide decision support for relevant personnel. Taking the panel data of 11 provinces and cities in China as samples, this paper makes an empirical analysis of the model. The results show that healthy human capital investment in coastal areas is generally high, and the relationship between healthy human capital and economic growth conforms to the inverted U-shaped development model, so we should pay attention to the reasonable proportion of healthy human capital investment. In addition, from the fitting effect of the regression model, the F-statistic values of model 1 and model 2 are 672.6327 and 1240.188, which shows that the fitting accuracy of the two regression models is higher.
\end{abstract}

Keywords: OLG model; health investment; economic development; private; public.

\section{RESUMO}

Como parte importante do capital humano, o capital humano saudável desempenha um grande papel na promoção do desenvolvimento econômico. Com base no modelo de gerações gerações sobrepostas (OLG), esteestudo estabelece um modelo de análise de correlação entre o capital humano saudável e o crescimento econômico. Este modelo leva à maximização da utilidade como suporte teórico para estudar como os indivíduos promovem o crescimento econômico, enquanto procedem à maximização de sua própria acumulação de capital saudável. O modelo pode analisar o mecanismo de promoção de capital humano saudável em crescimento econômico, de modo a fornecer suporte de decisão para os profissionais. Tomando os dados do painel de 11 províncias e cidades da China como amostra, o presente estudo faz uma análise empírica do modelo. Os resultados mostram que o investimento em capital humano para a saúde nas zonas costeiras é geralmente elevado, e a relação entre o capital humano saudável e o crescimento econômico está em conformidade com o modelo de desenvolvimento invertido em forma de U, pelo que devemos prestar atenção à proporção razoável de investimento em capital humano saudável. Além disso, a partir do efeito de ajuste do modelo de regressão, os valores F-estatísticos do modelo 1 e do modelo 2 são 672.6327 e 1240.188, o que mostra que a precisão de ajuste dos dois modelos de regressão é maior.

Descritores: Modelo OLG; investimento em saúde; desenvolvimento econômico; privado; público.

\section{RESUMEN}

Como parte importante del capital humano, la salud juega un papel importante en la promoción del desarrollo económico. Basado en el modelo de generaciones superpuestas (OLG), este estudio establece un modelo de análisis de correlación entre capital humano saludable y crecimiento económico. Este modelo toma la maximización de la utilidad como portador teórico para estudiar cómo los individuos promueven el crecimiento económico mientras persiguen la maximización de su propia acumulación de capital en salud. El modelo puede analizar el mecanismo de promoción del capital humano saludable sobre el crecimiento económico, a fin de brindar apoyo a las decisiones del personal relevante. Tomando como muestra los datos de panel de 11 provincias y ciudades de China, este artículo realiza un análisis empírico del modelo. Los resultados muestran que la inversión de capital humano saludable en las áreas costeras es generalmente alta, y la relación entre capital humano saludable y crecimiento económico se ajusta al modelo de desarrollo en forma de U invertida, por lo que debemos prestar atención a la proporción razonable de inversión de capital humano saludable. Además, del efecto de ajuste del modelo de regresión, los valores del estadístico F del modelo 1 y del modelo 2 son 672,6327 y 1240,188, lo que muestra que la precisión de ajuste de los dos modelos de regresión es mayor.

Palabras clave: Modelo OLG; inversión en salud; desarrollo económico; sector privado; sector público. 


\section{INTRODUCTION}

Health cannot only improve the production efficiency of workers, thus creating more market value, and indirectly improve the living income of the people. In addition, the improvement of workers' physical quality can bring greater economic benefits to individuals and society, so health has continuity and spontaneity for the national economy. If health is regarded as a normal product, from the perspective of maximizing individual interests, when there is income constraint, individuals will not increase private health consumption, because the increase of private health consumption is bound to crowd out physical capital investment, which is not conducive to the realization of self-interest maximization. However, many development examples show that the more sound the health care system, the richer the national wealth. On the contrary, improving the health care system in poor countries can not only improve the health quality of the people, but also bring a huge debt burden to the government, thus hindering the accumulation of material capital, reducing investment, and creating a huge obstacle to the national economic growth do Y.K.' Therefore, the relationship between healthy human capital investment and economic development is worth pondering. In view of this, from the connotation of health human capital, this paper discusses the impact of health human capital on economic development. ${ }^{2}$

OLG model, also known as diamond model, is an important model to establish micro basis in macro research. Based on the OLG model, this study constructs a correlation analysis model between health human capital and economic growth based on OLG framework, and studies the correlation mechanism between health human capital and economic growth from the perspective of intertemporal consumption of individuals and enterprises. ${ }^{3}$ The model assumes that agents in two periods will be impacted by special productivity when they are old. In the case of zero tax equilibrium, a combination of small capital tax and one-time transfer of total payment is constructed to realize Pareto improvement. The empirical results show that although the decrease of capital in a certain period will improve the welfare level of the old agent, it will reduce the welfare level of the young agent. Therefore, the government can compensate the wage loss of the young agent by imposing additional tax on the old employee, so that the social welfare income will keep positive growth. the first producing the original products and the second recycling the products from the previous period. When the profit of recycling sector is in the growth area, and leisure and consumption are complementary, endogenous fluctuations appear through the flip bifurcation. ${ }^{4}$ On the contrary, when the profit is in the declining area, the deterministic cycle will also appear under the total alternative assumption. Caravaggio A and his colleagues analyzed a model of overlapping generations in which economic activities depended on freely available natural resources. At the same time, they also studied the consequences of the interaction between environmental public expenditure and the private sector. Empirical results show that there is a positive effect between environmental public expenditure and the private sector. ${ }^{5}$ In 2008, India launched Rashtriya swasthya Bima Yojana (rsby), a publicly funded national health insurance scheme for people below the poverty line. discussed the origin and early development of rsby in order to understand the concept and design principles of rsby, so as to establish a baseline for evaluating the performance of rsby in the future. National and global health challenges are increasingly proving that economic prosperity is impossible when there is a huge knowledge and capacity gap in health systems. Public health initiatives aimed at strengthening health systems beyond sovereign borders are therefore necessary to influence the global geo economy. One belt, one road, is to strengthen public health investment and capacity building in the "one belt and one way" area. Through the summary of the above, we can find that there are many researches on health and economic development, and the research perspective is more in-depth, pointing out that national health plays a positive role in economic development. However, it is rare to divide health investment into public expenditure and private expenditure, and to comprehensively analyze the crowding out effect of physical capital. This is the important reason why we should use OLG model as the carrier to explore the impact of public health investment and private health investment on economic development. Health investment will be of great significance to the promotion of human capital.

\section{Empirical analysis of health human capital and economic growth model based on OLG}

The above model has proved that public health investment and private health investment have a positive effect on economic development in a certain range. Next, the panel data of 11 provinces and cities in China from 2002 to 2018 are taken as samples to verify the above conclusions. The indicators involved in the study are all macroeconomic indicators, which control the relationship between these variables and economic growth in the macro direction. This time, the annual average amount of government health expenditure is taken as the measurement index of public health expenditure, and the per capita health care consumption expenditure of urban residents is taken as the measurement index of private health expenditure. The economic growth is measured by GDP increment, and the data processing method is logarithm. The data involved are all from the statistical yearbook. After statistical analysis, the relationship between health investment, physical capital investment and GDP of various provinces and cities is obtained. The details are shown in Figure 1.

It can be seen from Figure 1 that public health investment, private health investment and per capita GDP of each province and province have a relatively close correlation effect. The former two have a promoting effect on per capita GDP, that is, the higher the public health investment, the higher the per capita GDP, and the higher the private health investment, the higher the per capita GDP. In order to analyze the relationship between health human capital and physical human capital, the physical capital investment and health human capital investment of sample provinces and cities were statistically analyzed. The statistical results are shown in Figure 2.

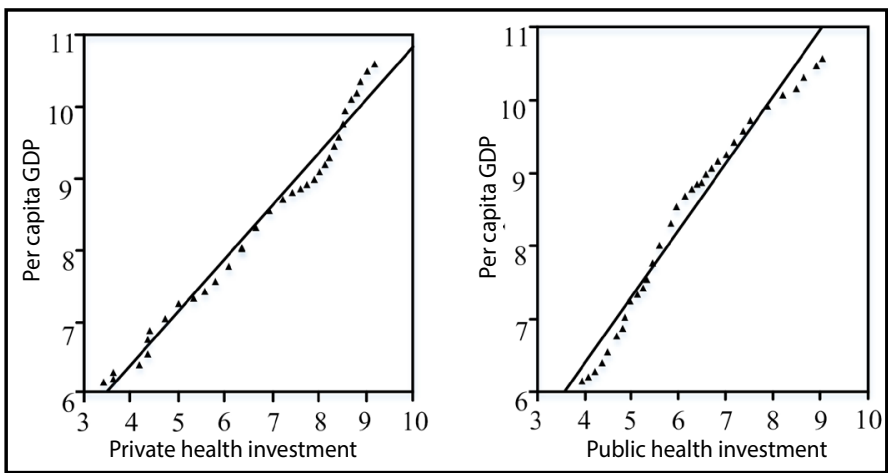

Figure 1. Relationship between health investment and private investment.

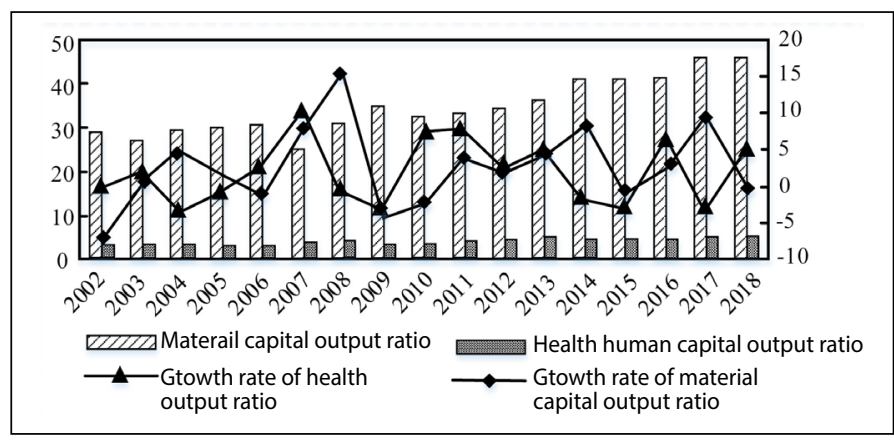

Figure 2. Relationship between health investment and private investment. 
As can be seen from Figure 2, the physical capital and health human capital of the sample provinces and cities show an upward trend. Among them, the growth rate of physical capital is relatively high, and the proportion of investment is relatively large. In recent years, almost all of them are stable at more than 35\%. Compared with the physical capital, the growth rate of healthy human capital is relatively low, and the proportion of investment is relatively small, only 5\%. Therefore, in the future development, health investment should be appropriately increased to promote rapid economic development. The main function of model 1 is to further analyze the impact of public health investment and private health investment portfolio on economic growth; the main function of model 2 is to analyze the impact of public health investment on economic growth.

It can be seen from Table 1 that both model 1 and model 2 have high fitting accuracy. The goodness of fit index of model 1 is 0.9956 , and that of model 2 is 0.9977 . Meanwhile, the Durbin Waston value of model 1 is 2.04, and that of model 2 is 1.93. In addition, the F-statistic value of model 1 is 672.6327 , and that of model 2 is 1240.188 . Therefore, on the whole, the two models have high fitting effect. From the regression results of group A, compared with the inland provinces and cities, Beijing, Shanghai, Zhejiang, Guangdong, Jiangsu and other coastal provinces and cities have higher heavy industry industrialization coefficient. The results show that the investment of health human capital in coastal areas is relatively high, and the implementation of the overall medical and health policy is relatively successful. Therefore, these areas have achieved greater economic growth under the promotion of health capital. However, when the investment of health human capital exceeds a certain amount, the health output benefit decreases, which reflects the negative effect of health human capital on economic growth.

According to the regression results of group B, although the public health investment and private health investment in Ningxia, Inner Mongolia, Yunnan and other regions are relatively strong, which promotes the local economic development to a certain extent, the proportion of the two is partially unbalanced, and the economic growth is limited; in

Table 1. Group A regression analysis.

\begin{tabular}{c|c|c|c|c}
\hline & \multicolumn{2}{|c|}{ Model 1 } & \multicolumn{2}{c}{ Model 2 } \\
\hline \multirow{2}{*}{ Province } & InIG/IP & InK & InK & InIG \\
\hline \multirow{2}{*}{ Beijing } & 0.671302 & 0.31632 & 0.109437 & 0.683583 \\
\cline { 2 - 5 } & $(8.521976)$ & $(6.127734)$ & $(2.264443)$ & $(12.9939)$ \\
\hline \multirow{2}{*}{ Shanghai } & 0.600360 & 0.193109 & 0.125722 & 0.534829 \\
\cline { 2 - 5 } & $(7.765660)$ & $(4.518374)$ & $(3.640349)$ & $(11.48117)$ \\
\hline \multirow{2}{*}{ Jiangsu } & 0.504307 & 0.318025 & 0.175899 & 0.484152 \\
\cline { 2 - 5 } & $(4.255800)$ & $(6.841883)$ & $(3.494910)$ & $(6.631420)$ \\
\hline \multirow{2}{*}{ Zhejiang } & 0.470183 & 0.350180 & 0.198692 & 0.488350 \\
\cline { 2 - 5 } & $(3.956082)$ & $(4.150478)$ & $(2.497052)$ & $(6.053139)$ \\
\hline \multirow{2}{*}{ Guangdong } & 0.340058 & 0.408276 & 0.289650 & 0.370763 \\
\cline { 2 - 5 } & $(4.089623)$ & $(8.639398)$ & $(6.359389)$ & $(6.751429)$ \\
\hline
\end{tabular}

addition, compared with the eastern developed provinces and cities, the medical and health system in these areas is still relatively backward (Table 2). Therefore, it is necessary for the state to increase the support for health investment in poor and backward areas to promote regional economic growth. However, the proportion of public health investment and private health investment should be balanced in order to realize the strong support of health human capital to economic growth.

Table 2. Group B regression analysis.

\begin{tabular}{c|c|c|c|c}
\hline I & \multicolumn{2}{|c|}{ Model 1 } & \multicolumn{2}{c}{ Model 2 } \\
\hline Province & InIG/IP & InK & InK & InIG \\
\hline \multirow{2}{*}{ Heilongjiang } & 0.11365 & 0.412553 & 0.34219 & 0.141495 \\
\cline { 2 - 5 } & $(0.834748)$ & $(5.558610)$ & $(3.972055)$ & $(1.527907)$ \\
\hline \multirow{2}{*}{ Inner Mongolia } & 0.51762 & 0.441674 & 0.327635 & 0.388826 \\
\cline { 2 - 5 } & $(4.994975)$ & $(10.5142)$ & $(7.221254)$ & $(6.929395)$ \\
\hline \multirow{2}{*}{ Ningxia } & 0.446005 & 0.408792 & 0.341624 & 0.358166 \\
\cline { 2 - 5 } & $(3.967350)$ & $(5.808288)$ & $(5.903245)$ & $(5.981672)$ \\
\hline \multirow{2}{*}{ Guangxi } & 0.220380 & 0.401917 & 0.284244 & 0.270514 \\
\cline { 2 - 5 } & $(2.82752)$ & $(8.608702)$ & $(4.717504)$ & $(4.019340)$ \\
\hline \multirow{2}{*}{ Shaanxi } & 0.229995 & 0.51006 & 0.405543 & 0.250552 \\
\cline { 2 - 5 } & $(2.175610)$ & $(6.672380)$ & $(5.616185)$ & $(3.747457)$ \\
\hline \multirow{2}{*}{ Yunnan } & 0.093818 & 0.52902 & 0.361773 & 0.247804 \\
\cline { 2 - 5 } & $(0.766002)$ & $(5.763486)$ & $(2.955646)$ & $(1.941332)$ \\
\hline
\end{tabular}

\section{CONCLUSIONS}

As a new engine of economic development, public health and private health investment have a greater role in promoting economic growth. Based on the analysis of OLG model, this study constructs a health human capital and economic growth model, which points out that there is an inverted U-shaped relationship between health human capital and economic growth. In the study, the panel data of 11 provinces and cities in China are taken as samples to conduct empirical analysis. The results show that the provinces and cities with higher health investment have higher economic growth rate and better overall development. In addition, the regression results show that compared with the inland provinces and cities, Beijing, Shanghai, Zhejiang and other coastal provinces and cities have higher heavy industry industrialization coefficient. The results show that the investment of health human capital in coastal areas is higher, and the implementation of the overall health policy is more successful. Therefore, these areas have achieved greater economic growth under the promotion of health capital, but the promotion effect of health investment on economic growth is weakened when the health investment exceeds a certain amount. In addition, the Durbin Waston values of model 1 and model 2 are 2.04 and 1.93 , respectively. Overall, the two regression models have high fitting accuracy.

The author declare no potential conflict of interest related to this article

AUTHORS' CONTRIBUTIONS: The author has completed the writing of the article or the critical review of its knowledge content. This paper can be used as the final draft of the manuscript. Every author has made an important contribution to this manuscript. Shuihui Jiang: writing and executing.

\section{REFERENCES}

1. Do YK, Bautista MA. Tobacco use and household expenditures on food, education, and healthcare in low- and middle-income countries: a multilevel analysis. Bmc Public Health. 2015; 15(1):1-11.

2. Diugwu IA, Mohammed M, Baba DL. Towards Effective Infrastructure Development in Nigeria: Theoretical Considerations from a Project Management Perspective. American Journal of Industrial \& Business Management. 2015; 5(4):172-180.

3. Bloom DE, Kuhn M, Prettner K. Invest in women and prosper: Investments in women's health and education boost economic development. Finance and Development. 2017; 54(3):50-65.

4. Abdullah NN, Othman MB. The Contribution of Human Capital Investment in the Growth of East Asian Economy-A Literature Review. Social Science Electronic Publishing. 2016; 22(1):190-203.

5. Caravaggio A, Sodini M. Multiple attractors and dynamics in an OLG model with productive environment. Communications in Nonlinear Science and Numerical Simulation. 2017; 58(MAY):167-184. 